\title{
Bacteriological profile, risk factors and antimicrobial susceptibility patterns of symptomatic urinary tract infection among students of Mekelle University, northern Ethiopia
}

Guesh Gebremariam ${ }^{1,2^{*}}$ (D), Haftom Legese ${ }^{1}$, Yemane Woldu², Tadele Araya ${ }^{2}$, Kiflom Hagos $^{2}$ and Araya GebreyesusWasihun²

\begin{abstract}
Background: Bacterial infection of the urinary tract is among the common reasons for seeking medical attention in the community. Rapidly increasing antibiotic resistance of uropathogens is resulting in limited treatment options. Therefore, knowledge of the current uropathogens and their antibiotic susceptibility is important for better treatment of urinary tract infection.

Methods: A cross-sectional study design was conducted from February to September thirty, 2017 among students who came to Mekelle University student's clinics with symptomatic urinary tract infection during the study period.. Mid-stream urine specimens were collected from 341 individuals with suspected urinary tract infection for bacteriological identification and antimicrobial susceptibility testing. Data on socio-demographic, clinical and risk factors were also collected using a structured questionnaire.

Results: Among the 341 study participants, 72(21.1\%) showed significant bacteriuria. Escherichia coli (48.6\%), Coagulase-negative staphylococci (23\%), Staphylococcus aureus (13.5\%), and Klebsiella spp. (8.1\%) were common bacterial isolates. Resistance to ampicillin (81-100\%), amoxicillin/clavulanic acid (77-93.6\%), co- trimoxazole (55 72.3\%), nalidixic acid (57.4\%) and tetracycline (46-55.5\%) was seen by most isolates. Multidrug resistance was observed in 73\% of the bacterial isolates, and $25.5 \%$ of the Gram-negative isolates were extended-spectrum beta-lactamase producers. Being female, a history of urinary tract infection, a history of catheterization and frequent sexual activity were found to be statistically associated with urinary tract infection.
\end{abstract}

Conclusion: Urinary tract infection is a problem among university students with a prevalence of $21.1 \%$. All isolates have developed resistance to most of the commonly used antibiotics. Therefore, health education on the transmission and causes of urinary tract infection are recommended for the students.

Keywords: Urinary tract infection, Antibiotic susceptibility, Bacteriological profile, Ethiopia, Mekelle University

\footnotetext{
*Correspondence: gueshgebre60@gmail.com

'Department of Medical Laboratory, College of Medicine and Health Science,

Adigrat University, P.O. Box, 50, Adigrat, Ethiopia

${ }^{2}$ Department of Microbiology and Immunology, Institute of Biomedical

Sciences, College of Health Science, Mekelle University, P.O. Box, 1870,

Mekelle, Ethiopia
}

(c) The Author(s). 2019 Open Access This article is distributed under the terms of the Creative Commons Attribution 4.0 International License (http://creativecommons.org/licenses/by/4.0/), which permits unrestricted use, distribution, and reproduction in any medium, provided you give appropriate credit to the original author(s) and the source, provide a link to the Creative Commons license, and indicate if changes were made. The Creative Commons Public Domain Dedication waiver (http://creativecommons.org/publicdomain/zero/1.0/) applies to the data made available in this article, unless otherwise stated. 


\section{Background}

Urinary Tract Infection (UTI) is the presence of significant bacteria in urine irrespective of the site of infection in the urinary tract [1].UTI can range from the presence of bacteria in urine without symptoms to serious symptomatic illnesses such as urethritis (urethra), cystitis (bladder), urethritis (ureters), and pyelonephritis (kidney) [2, 3]. It is the most common cause of morbidity in the general population and hospital visit $[4,5]$.

Globally, 150 million people are diagnosed with UTI yearly $[6,7]$ which causes an expense of greater than 6 billion US dollars healthcare expenditure in treatment and work loss [8].

UTI occurs in all age groups of both genders [4, 9]. This is as a result of anatomic position, physiological changes, vaginal intercourse, use of contraceptive methods like spermicide and diaphragm, and lack of prostatic fluid which acts as an antibacterial agent, almost $50 \%$ of women experiencing at least one episode of UTI during their lifetime $[1,10,11]$. Even though the episode of UTI is less in men than females, it is more serious when it happens $[12,13]$.

Despite these clear increased risks of UTI, clinicians lack scientifically valid methods to identify and ultimately treat patients with UTI complains $[14,15]$. Therefore, UTI can cause serious complications such as frequent recurrences, bacteremia, and renal failure, preterm delivery $[16,17]$.

UTI among university students is commonly similar to the general population and the majority of the females have recurrent infections within 1 year [18]. The prevalence of UTI in India and Saudi Arabia among College students were found to be 19.8 and $32.1 \%$ respectively $[5,19]$. UTI among university students of Africa (Nigeria) has been reported as 28\% [20].

The causative agent of UTI is predominantly associated with Gram-negative bacteria such as E. coli (7590\%), Klebsiella spp. Proteusspp., and Gram-positive bacteria such as coagulase-negative staph (CoNS) and S.aureus [21].

Nowadays, uropathogen isolates are alarmingly exhibited a high percentage of resistance to almost all antibiotics worldwide [22]. This owning to the irrational use of antibiotics among university students [23-26].

In Ethiopia concerning the prevalence and antimicrobial susceptibility pattern of UTIs among hospital patients varies from area to area $[7,27]$, and there is no published data in Mekelle city as well as in Ethiopia concerning the UTI among University students. Updated information on UTI and its prevalence and resistance patterns are very important for the proper selection and use of antimicrobial agents in a setting. Thus, this study was aimed to assess bacteriological profile, risk factors and antimicrobial susceptibility patterns of symptomatic urinary tract infection among students of Mekelle University, northern Ethiopia.

\section{Methods \\ Study design, period and area}

A laboratory-based cross-sectional study was conducted from February to September thirty, 2017 among university students at Mekelle University, Mekelle, northern Ethiopia. Mekelle city is the capital city of Tigray Regional State and found at a distance of $783 \mathrm{~km}$ from Addis Ababa which is the capital city of Ethiopia. Its elevation is $2084 \mathrm{~m}$ above sea level with an area of 24.4 $\mathrm{km}^{2}$. The region has four universities among that one is MekelleUniversity which has five campuses. The names of the campuses are Endayesus main campus, Adi Haqi campus (College of Business and Economics), Ayder campus (College of Health Sciences and Ayder Referral Hospital), Kalamino Campus (College of Veterinary Medicine), Aynalem campus (Mekelle Institute of Technology).

\section{Sample size determination and sampling technique}

The sample size was determined using the single population proportion formula.

$$
\mathrm{n}=\frac{\mathrm{Z}^{2} \alpha / 2 \mathrm{P}(1-\mathrm{P})}{\mathrm{d}^{2}}
$$

Since there was no data in Ethiopia, the prevalence of UTI among university students was taken from Nigeria (28\%) which was done by Nwosu et al [20]. Then with a margin of error $(5 \%),(d=0.05)$ and $95 \%$ level of confidence $(\mathrm{z}=1.96)$, the sample size was calculated as follows:

$$
\mathrm{n}=\frac{(1.96)^{2} * 0.28(1-0.28)}{(0.05)^{2}}=310 \text { plus contingency } 10 \% \text { so, } 310+31=341
$$

Therefore, a total of 341 UTI suspected students were included in the study from all campuses of the university. A convenient sampling technique was used to select study participants from each campus of MU student's clinic during the study period.

The distribution of the 341 study participants into each campus was done based on proportion to the size of the source population of each campus using proportionate allocation formula.

\section{Data collection and laboratory processing}

Data related to socio-demographic characteristics (gender, age, residence), risk factor associated with UTI (sexual activity, history of UTI,contraceptive use, history of catheterization, history of diabetes mellitus and circumcision [2], and clinical data such as Hematuria/dark Flank pain, urgency frequency,dysuria, 
abdominal discomfort and urinary incontinence were collected by direct interview of the study participants in combination with a review of medical records. All the questionnaires were checked for accuracy and completeness. After proper instruction, female study participates were informed to clean their peri-urethral area with water and soap then cleanse with sterile gauze to collect $5-10 \mathrm{ml}$ of freshly voided midstream urine using sterile and wide-mouthed plastic bottles with a tight cap. Then the collected midstream urine specimens were transported to Ayder referral hospital medical microbiology lab using $(0.1 \mathrm{~g})$ boric acid preservative. Urine specimens were processed in the laboratory within $2 \mathrm{~h}$ of collection and specimens that are not processed within $2 \mathrm{~h}$ were kept refrigerated at $4{ }^{\circ} \mathrm{C}$ until analyzed $[28,29]$.

\section{Cultivation and identification isolates}

Using calibrated inoculating loop $0.001 \mathrm{~mL}$ [2] of uncentrifuged, uniformly mixed, midstream urine samples were aseptically inoculated onto mannitol salt agar (Oxiod, Hampisher, UK), blood agar (Oxiod, Hampshier, UK) and MacConkey agar (Oxiod, Hampshier, UK). After overnight incubation at $37^{\circ} \mathrm{C}$ for $24-48 \mathrm{~h}$ colonies were counted to check significant growth. Colony counts yielding bacterial growth of $105 / \mathrm{mL}$ of urine were regarded as significant for bacteriuria [30]. All positive urine cultures with significant bacteriuria were further identified by their colony characteristics, Gram-stain, and pattern of biochemical profiles using standard procedures. Enterobacteriaceae were identified by $\mathrm{H}_{2} \mathrm{~S}$ production and carbohydrate utilization tests in TSI agar, motility test, urease test, oxidase, indole test, and citrate tests. The Gram-positive bacteria were identified using catalase and coagulase tests $[6,29]$.

\section{Antimicrobial susceptibility testing}

Antimicrobial susceptibility test was performed using a modified Kirby- Bauer disc diffusion method according to Clinical and Laboratory Standards Institute (CLSI) guidelines, [31]. The following antibiotics were used: ampicillin (AMP; $10 \mu \mathrm{g}$ ), ceftriaxone (CTR; $30 \mu \mathrm{g}$ ), chloramphenicol $(\mathrm{C} ; 30 \mu \mathrm{g})$, amoxicillin/clavulanic acid (AMC; 20/10 $\mu \mathrm{g}$ ), erythromycin (ERY; $15 \mu \mathrm{g}$ ), gentamicin (GEN; $10 \mu \mathrm{g}$ ), nalidixic acid (NA; $30 \mu \mathrm{g}$ ), nitrofurantoin (NIT; $300 \mu \mathrm{g}$ ),co-trimozaxole (COT; $25 / 125 \mu \mathrm{g}$ ), ciprofloxacin (CIP; $5 \mu \mathrm{g})$,norfloxacin $(\mathrm{Nx} ; 10 \mu \mathrm{g})$ and tetracycline $(\mathrm{TE} ; 30 \mu \mathrm{g})$. Isolates were classified as sensitive, intermediate and resistant according to the standardized table supplied by CLSI 2016 [32] .ESBL screening was also performed based on the disk diffusion clavulanate inhibition test using ceftazidime /clavulanic acid, ceftazidime, and cefotaxime (Himedia) antibiotic discs [32].

\section{Quality control}

Strict measures were taken from the pre-analytical to the post-analytical phase. The questionnaire was pretested in 17 patients with symptomatic urinary tract infection at Adigrat university student clinic, Northern Ethiopia. As part of quality assurance, 2 days of training was given for data collectors on how to perform the questionnaire and sampling process. The legibility of the filled questionnaire and any labeling errors were confirmed immediately. Laboratory analyses were carried out using standard operating procedures. Culture media were tested for sterility and performance by incubating $5 \%$ of the batch [21]. Standard reference strains of Staphylococcus aureus (ATCC25923), Escherichia coli (ATCC25922), P. aeruginosa (ATCC27853) and P.mirabilis (ATCC 25659) were used during culture and antimicrobial susceptibility testing.

\section{Data processing and analysis}

Data were edited, cleaned, entered and analyzed using statistical package for social science (SPSS) version 22. Descriptive statistics, Bivariate, and multivariate logistic regression were performed. Bivariate logistic regression was employed to look association between the outcome variable and each independent variable. A binary logistic regression analysis was used to calculate the odds ratios (OR); Crude Odds Ratio (COR) and Adjusted Odds Ratio (AOR) to ascertain the degree of association between risk factors of symptomatic urinary tract infection. In this study, multicollinearity among independent variables was detected using the standard errors for regression coefficients. The corresponding variables with $P$-value $(P<0.05)$ and the $95 \%$ confidence interval were then considered as statistically significant differences.

\section{Results}

\section{Socio-demographic characteristics}

Out of 341 eligible students with symptoms of urinary tract infection, all are agreed to participate in this study, which made a response rate of $100 \%$. Of whom, 244(71.6\%) were females and 97(28.4\%) were males with a 1:2.5 male to female ratio. The majority of the study participants $217(63.6 \%)$ were in the age group of $21-25$ years, and the mean age of participants was $23( \pm 2.2 \mathrm{SD})$ with the age range of 18 - 35 years [Table 1].

\section{Prevalence of urinary tract infection}

Of the 341 urine specimens analyzed, 72(21.1\%) had significant bacteriuria $\left(\geq 10^{5} \mathrm{cfu} / \mathrm{mL}\right)$. The highest significant bacteriuria $(23.3 \%)$ was observed in participants with the age group of $26-30$ years [Table 2]. 
Table 1 Socio-demographic characteristics of the Study Participants with Symptomatic UTI $((N=341)$ at Mekelle University, northern Ethiopia, February-September 2017

\begin{tabular}{lll}
\hline Variables & Frequency & Percent (\%) \\
\hline Sex & 97 & 28.4 \\
Male & 244 & 71.6 \\
Female & & \\
Age (in years) & 29 & 8.5 \\
16-19 & 217 & 63.6 \\
21-25 & 90 & 26.4 \\
26-30 & 5 & 1.5 \\
31-35 & & \\
Stay at Mekelle University (in years) & 60 & 17.6 \\
1st & 77 & 22.6 \\
2nd & 91 & 26.7 \\
3rd & 73 & 21.4 \\
4th & 40 & 11.7 \\
5th and above & & \\
Residence (Campuses) & 206 & 60.4 \\
Arid (Main Campus) & 89 & 26.1 \\
Adi Haqi & 34 & 9.9 \\
Ayder & 6 & 1.8 \\
Aynalam & 6 & \\
Kalamino & & \\
\hline
\end{tabular}

Table 2 Prevalence of UTI with Regard to the SocioDemographic Characteristics among Mekelle UniversityStudents with Symptomatic UTI, northern Ethiopia, February-September 2017

\begin{tabular}{|c|c|c|c|c|}
\hline \multirow[t]{2}{*}{ Variables } & \multicolumn{2}{|c|}{ Significant Bacteriuria } & \multirow[t]{2}{*}{ Percentage } & \multirow[t]{2}{*}{ Total } \\
\hline & Yes (\%) & No (\%) & & \\
\hline \multicolumn{5}{|l|}{ Sex } \\
\hline Male & $8(8.2)$ & 89(91.8) & 28.4 & 97 \\
\hline Female & $64(26.2)$ & 180(73.8) & 71.6 & 244 \\
\hline \multicolumn{5}{|l|}{ Age (in years) } \\
\hline $16-20$ & $5(17.2)$ & $24(82.8)$ & 8.5 & 29 \\
\hline $21-25$ & $46(21.2)$ & $171(78.8)$ & 63.6 & 217 \\
\hline $26-30$ & 21(23.3) & $69(76.7)$ & 26.4 & 90 \\
\hline $31-35$ & $0(0.0)$ & $5(100.0)$ & 1.5 & 5 \\
\hline \multicolumn{5}{|l|}{ Residence (Campuses) } \\
\hline Arid (Main Campus) & $39(19)$ & $167(81)$ & 60.4 & 206 \\
\hline Adi Haqi & 21(23.4) & 68 & 26.1 & 89 \\
\hline Ayder & $11(32.4$ & 23(67.6) & 9.9 & 34 \\
\hline Aynalam & $0(0.0)$ & $6(100)$ & 1.8 & 6 \\
\hline Kalamino & $1(16.7)$ & $5(83.3)$ & 1.8 & 6 \\
\hline
\end{tabular}

\section{Bacterial uropathogens}

Of the total 74 isolates, $47(63.5 \%)$ were Gramnegative while $27(36.5 \%)$ were Gram-positive bacteria. Overall, E.coli was the dominant bacterial isolates 36(48.6\%) followed by Coagulase-negative staphylococci (CoNS) 17(23\%), S. aureus 10(13.5\%) and K.pneumonie 6(8.1\%). Of all, mixed pathogens were isolated from 2(2.8\%) patients [Fig. 1].

\section{Antimicrobial susceptibility pattern of bacterial uropathogens \\ Gram negative bacteria}

Gram negative isolates were resistant to ampicillin (100\%), amoxicillin/clavulanic acid(93.6\%), co-trimexazole(72.3\%), nalidixic acid $(57.4 \%)$, tetracycline $(46.8 \%)$, gentamicin (29.8\%) and chloramphenicol (25.5\%).Antibiotics such as ciprofloxacin (85.1\%), ceftriaxone $(83.0 \%)$, norfloxacin $(80.8 \%)$ and nitrofurantoin $(78.7 \%)$ were more effective for the isolates [Table 3].

\section{Gram-positive bacteria}

Out of the tested antibiotics, Gram-positive bacterial isolates were highly resistant to ampicillin (81.5\%), amoxicillin/clavulanic acid (77.8\%), co-trimoxazole (55.6\%) and tetracycline (55.5\%). Among the tested antibiotics, ciprofloxacin (88.9\%), gentamicin (85.2\%), chloramphenicol $(81.5 \%)$, nitrofurantoin $(81.5 \%)$, ceftriaxone and erythromycin $(74.1 \%$ each), and norfloxacin $(70.4 \%)$ were effective to Gram-positive isolates [Table 4].

\section{Multiple drug resistance (MDR) patterns of the isolates}

Among the total bacterial uropathogens isolates $(N=$ 72 ), the overall prevalence of MDR in the present study was 54(73\%). The prevalence of MDR for Gram-negative and positive isolates were $41(87.2 \%)$ and $13(48.1 \%)$, respectively [Table 5].

\section{Extended-spectrum beta-lactamase (ESBL) production}

Of the 47 Gram-negative isolates, $12(25.5 \%)$ were positive to ESBL production with10 (27.8\%) of the E.coli isolates and 2(33.3\%) of K.pnuemoniae.

\section{Factors associated with bacterial urinary tract infections} Bivariate and multivariate logistic regression analyses were performed to assess the association between dependent and independent study variables. According to the bivariate analysis, being female, previous history of UTI, sexual activity, history of catheterization, uncircumcised male, contraceptive user females, Dysuria, Frequency, Urgency, Hematuria, Flank pain, and Urinary incontinence were showed association with symptomatic urinary tract infection and transported to multivariate analysis. Accordingly, in multivariate analysis, being female ( $\mathrm{AOR}=7.42$, 


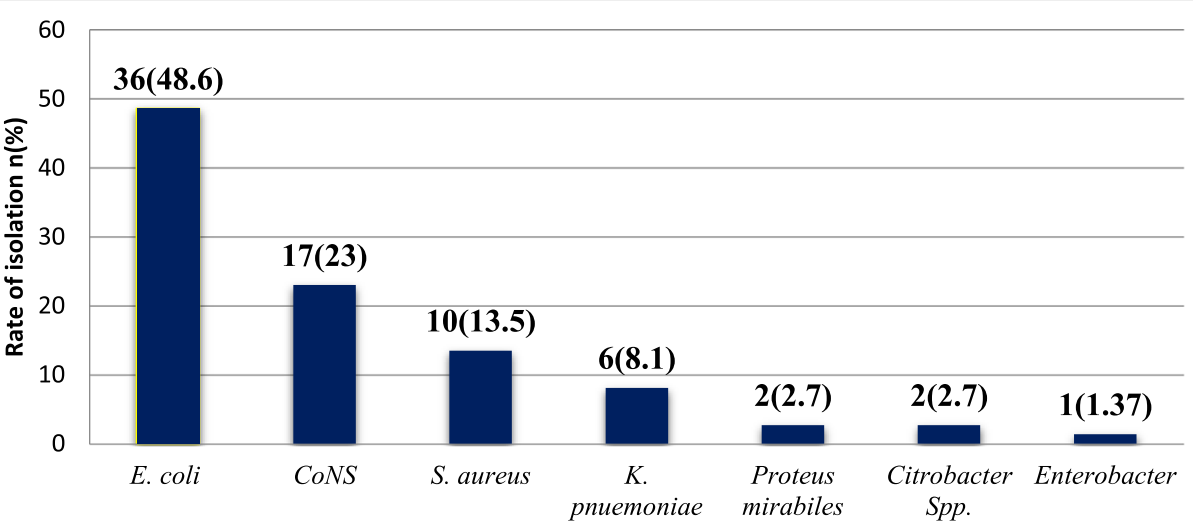

Uropathogen bacterial isolates

Fig. 1 Frequency of bacterial uropathogen isolates among Mekelle University Studentswith symptomatic UTI, northern Ethiopia, February-September 2017

95\% CI: $1.25-43.96, p=0.027)$, previous history of UTI $(\mathrm{AOR}=5.75,95 \%, \quad \mathrm{CI}: 1.70-19.4, \quad p=0.005)$, sexual activity $(\mathrm{AOR}=2.16,95 \% \mathrm{CI}: 1.149-3.69, p=$ 0.012 ) and history of catheterization $(\mathrm{AOR}=18.2,95 \%$ CI: 4.45-74.77, $p \leq 0.001)$ were significantly factors associated with urinary tract infections. Among the currently observed symptoms of UTI, flank pain $(\mathrm{AOR}=3.776, \quad 95 \% \quad \mathrm{CI}: \quad 1.55-9.18, \quad p=0.003) \quad$ was significantly associated with urinary tract infections [Tables 6 and 7].

Table 3 Antimicrobial Susceptibility Pattern of Gram Negative Bacterial Isolates among Mekelle University Students with Symptomatic UTI, northern Ethiopia, February-September 2017

\begin{tabular}{|c|c|c|c|c|c|c|c|c|c|c|c|c|}
\hline \multirow[t]{2}{*}{ Bacterial Isolates(n) } & & \multicolumn{11}{|c|}{ Antibiotics } \\
\hline & & $\overline{\mathrm{AMP}}$ & AMC & CTR & NX & GEN & NA & NIT & CIP & COT & $\mathrm{TE}$ & $C$ \\
\hline \multirow[t]{3}{*}{$\overline{\text { E. coli (36) }}$} & $S$ & $0(0.0)$ & $2(5.6)$ & $29(80.6)$ & $30(83.3)$ & $25(69.5)$ & $15(41.7)$ & $29(80.6)$ & $30(83.3)$ & 11(30.6) & $21(58.3)$ & $29(80.6)$ \\
\hline & । & $3(8.3)$ & $3(8.3)$ & $0(0.0)$ & $2(5.6)$ & $8(22.2)$ & $5(13.9)$ & $2(5.6)$ & $3(8.3)$ & $3(8.3)$ & $3(8.3)$ & $0(0.0)$ \\
\hline & $\mathrm{R}$ & 33(91.7) & $31(86.1)$ & $7(19.4)$ & $4(11.1)$ & $3(8.3)$ & $16(44.4)$ & $5(13.8)$ & $3(8.3)$ & $22(61.1)$ & $12(33.3)$ & $7(19.4)$ \\
\hline \multirow[t]{3}{*}{ K. pneumoniae (6) } & $S$ & $0(0.0)$ & $1(16.7)$ & $5(83.3)$ & $4(66.7)$ & $4(66.7)$ & $3(50.0)$ & $3(50.0)$ & $5(83.3)$ & $1(16.7)$ & $1(16.7)$ & $3(50.0)$ \\
\hline & 1 & $1(16.7)$ & $1(16.7)$ & $0(0.0)$ & $1(16.7)$ & $0(0.0)$ & $1(16.7)$ & $0(0.0)$ & $1(16.7)$ & $1(16.7)$ & $2(33.3)$ & $2(33.3)$ \\
\hline & $\mathrm{R}$ & $5(83.3)$ & $4(66.7)$ & $1(16.7)$ & $1(16.7)$ & $2(33.3)$ & $2(33.3)$ & $3(50.0)$ & $0(0.0)$ & $4(66.7)$ & $3(50.0)$ & $1(16.7)$ \\
\hline \multirow[t]{3}{*}{ P. mirabilis (2) } & $\mathrm{S}$ & $0(0.0)$ & $0(0.0)$ & $2(100)$ & $1(50.0)$ & $2(100)$ & $1(50.0)$ & $2(100)$ & $2(100)$ & $1(50.0)$ & $1(50.0)$ & $2(100)$ \\
\hline & I & $0(0.0)$ & $1(50.0)$ & $0(0.0)$ & $0(0.0)$ & $0(0.0)$ & $0(0.0)$ & $0(0.0)$ & $0(0.0)$ & $0(0.0)$ & $0(0.0)$ & $0(0.0)$ \\
\hline & $\mathrm{R}$ & $2(100)$ & $1(50.0)$ & $0(0.0)$ & $1(50.0)$ & $0(0.0)$ & $1(50.0)$ & $0(0.0)$ & $0(0.0)$ & $1(50.0)$ & $1(50.0)$ & $0(0.0)$ \\
\hline \multirow[t]{3}{*}{ Citrobacter spp. (2) } & $S$ & $0(0.0)$ & $0(0.0)$ & $2(100)$ & $2(100)$ & $1(50.0)$ & $1(50.0)$ & $2(100)$ & $2(100)$ & $0(0.0)$ & $1(50.0)$ & $1(50.0)$ \\
\hline & 1 & $0(0.0)$ & $0(0.0)$ & $0(0.0)$ & $0(0.0)$ & $1(50.0)$ & $0(0.0)$ & $0(0.0)$ & $0(0.0)$ & $0(0.0)$ & $1(50.0)$ & $0(0.0)$ \\
\hline & $\mathrm{R}$ & $2(100)$ & $2(100)$ & $0(0.0)$ & $0(0.0)$ & $0(0.0)$ & $1(50.0)$ & $0(0.0)$ & $0(0.0)$ & $2(100)$ & $0(0.0)$ & $1(50.0)$ \\
\hline \multirow[t]{3}{*}{ Enterobacter spp.(1) } & $S$ & $0(0.0)$ & $0(0.0)$ & $1(100)$ & $1(100)$ & $1(100)$ & $0(0.0)$ & $1(100)$ & $1(100)$ & $0(0.0)$ & $1(100)$ & $0(0.0)$ \\
\hline & । & $0(0.0)$ & $0(0.0)$ & $0(0.0)$ & $0(0.0)$ & $0(0.0)$ & $1(100)$ & $0(0.0)$ & $0(0.0)$ & $0(0.0)$ & $0(0.0)$ & $1(100)$ \\
\hline & $\mathrm{R}$ & $1(100)$ & $1(100)$ & $0(0.0)$ & $0(0.0)$ & $0(0.0)$ & $0(0.0)$ & $0(0.0)$ & $0(0.0)$ & $1(0.0)$ & $0(0.0)$ & $0(0.0)$ \\
\hline \multirow[t]{3}{*}{ Total n (\%) } & $S$ & $0(0.0)$ & $3(6.4)$ & 39(83.0) & $38(80.8)$ & $33(70.2)$ & $20(42.6)$ & $37(78.7)$ & $40(85.1)$ & 13(27.7) & $25(53.1)$ & $35(74.5)$ \\
\hline & 1 & $4(8.5)$ & $5(10.7)$ & $0(0.0)$ & $3(6.4)$ & $9(19.2)$ & $7(14.8)$ & $2(4.3)$ & $4(8.5)$ & $4(8.5)$ & $6(12.8)$ & $3(6.4)$ \\
\hline & $\mathrm{R}$ & 43(91.5) & 39(82.9) & $8(17.0)$ & $6(12.8)$ & $5(10.6)$ & $20(42.6)$ & $8(17.0)$ & $3(6.4)$ & $30(63.8)$ & $16(34.0)$ & $9(19.1)$ \\
\hline
\end{tabular}

Key; AMC Amoxacillin clavulanic acid, AMP Ampicillin, NA Nalidixic acid, NX Norfloxacilin, NIT Nitrofruinton, CTR Ceftriaxone, GEN Gentamicin, COT Co-trimexazole, TE Tetracycline, C Chloramphenicol, CIP Ciprofloxacin, S Susceptible, I Intermediate, $R$ Resistant. \% is computed from each cell. Total total resistance of gram negative isolates for the specific tested 
Table 4 Antimicrobial Susceptibility Patterns of Gram Positive Bacterial Isolates among Mekelle University Students with Symptomatic UTI, Northern Ethiopia, February-September 2017

\begin{tabular}{|c|c|c|c|c|c|c|c|c|c|c|c|c|}
\hline \multirow{2}{*}{$\begin{array}{l}\text { Bacterial } \\
\text { isolate(n) }\end{array}$} & & \multicolumn{11}{|c|}{ Antibiotics } \\
\hline & & AMP & AMC & CTR & $N X$ & GEN & NIT & CIP & COT & TE & ERY & $C$ \\
\hline \multirow[t]{3}{*}{ CONS (17) } & $S$ & $4(23.5)$ & $5(29.4)$ & $15(88.2)$ & $12(70.6)$ & $17(100)$ & 16(94.1) & $17(100)$ & 10(58.8) & $8(47.1)$ & $9(52.9)$ & $14(82.3)$ \\
\hline & 1 & $1(5.9)$ & 1(5.9) & $1(5.9)$ & $2(11.8)$ & $0(0.0)$ & $1(5.9)$ & $0(0.0)$ & $1(5.9)$ & 6(35.3) & $2(11.8)$ & $1(5.9)$ \\
\hline & $\mathrm{R}$ & 12(70.6) & $11(64.7)$ & $1(5.9)$ & $3(17.6)$ & $\mathrm{O}(0.0)$ & $0(0.0)$ & $0(0.0)$ & 6(35.3) & $3(17.6)$ & $6(35.3)$ & $2(11.8)$ \\
\hline \multirow[t]{3}{*}{ S.aureus (10) } & $S$ & $1(10.0)$ & $1(10.0)$ & $6(60.0)$ & 7(70.0) & $6(60.0)$ & $6(60.0)$ & 7(70.0) & $2(20.0)$ & $4(40.0)$ & $5(50.0)$ & $4(80.0)$ \\
\hline & 1 & $0(0.0)$ & $1(10.0)$ & $1(10.0)$ & $0(0.0)$ & $1(10.0)$ & $0(0.0)$ & $0(0.0)$ & $1(10.0)$ & $0(0.0)$ & $0(0.0)$ & $0(0.0)$ \\
\hline & $\mathrm{R}$ & $9(90.0)$ & $8(80.0)$ & $3(30.0)$ & $3(30.0)$ & $3(30.0)$ & $4(40.0)$ & $3(30.0)$ & 7(70.0) & $6(60.0) c$ & $5(50.0)$ & $6(60.0)$ \\
\hline \multirow[t]{3}{*}{ Total n (\%) } & S & $5(18.5)$ & $6(22.2)$ & $21(77.8)$ & 19(70.4) & 23(85.2) & $22(81.5)$ & $24(88.9)$ & $12(44.4)$ & $12(44.4)$ & $14(51.9)$ & 18(66.6) \\
\hline & I & $1(3.7)$ & $2(7.4)$ & $2(7.4)$ & $2(7.4)$ & $1(3.7)$ & $1(3.7)$ & $0(0.0)$ & $2(7.4)$ & $6(22.2)$ & $2(7.4)$ & $1(3.7)$ \\
\hline & $\mathrm{R}$ & $21(77.8)$ & 19(70.) & $4(14.8)$ & $6(22.2)$ & $3(11.1)$ & $4(14.8)$ & $3(11.1)$ & $13(48.2)$ & $9(33.3)$ & $11(40.7)$ & $8(29.6)$ \\
\hline
\end{tabular}

Key; AMC Amoxacillin clavulanic acid, AMP Ampicillin, NX Norfloxacilin, NIT Nitrofruinton, CTR Ceftriaxone, GEN Gentamicin, COT Co-trimexazole, TE Tetracycline, ERY Erythromycin, C Chloramphenicol, CIP Ciprofloxacin, S Susceptible, I Intermediate, $R$ Resistant. \% is computed from each cell, Total total resistance of gram positive isolates for the specific tested

\section{Discussion}

Urinary tract infection (UTI) remains to be one of the most common infectious diseases diagnosed in the community [33, 34].

The overall prevalence of UTI in this study was found to be $21.1 \%$; which was in agreement with the findings of the previous studies conducted in Ethiopia from the general population (23.32\%) [35]; Keffi, Nigeria (20\%) [36] and Ogun State, Nigeria (25\%) [37]; India (19.8\%) [13] and (22\%) [38]. However, our finding was higher than other earlier studies reported in Southeast Nigeria (13.8\%) [39]; and BeninCity, Nigeria (11\%) [40] and (8.25\%) [41]. But it was lower compared to other studies done in Nigeria, Imo State University (28\%) [20] southeastern Nigeria (78\%) [42]. This difference in the rate of UTI may be explained by variation in the methodology used, sexual behavior (those sexually active individuals are more exposed to urinary tract infection). This is due to ascending infection from genital to the urinary tract, climatic and geographic variation might be attributed to cold climate that leads to alack of personal and environmental hygiene of participants, lack of sanitary materials in the university such as access of water, low socioeconomic status similar to the previous finding in Iran [3], majority of the isolates (89.2\%) were from female participants which support the implication of females are at high risk for UTI [10, 11]. This high prevalence of UTI among female participants may be due to females have shorter and wider urethra which is proximate to the anus, lack of prostatic fluid which acts

Table 5 Level of Antimicrobial Resistance of Uropathogen Bacterial Isolates among Mekelle University Students with Symptomatic UTI, Northern Ethiopia, February-September 2017

\begin{tabular}{|c|c|c|c|c|c|c|c|c|}
\hline \multirow{2}{*}{$\begin{array}{l}\text { Bacterial } \\
\text { isolates(n) }\end{array}$} & \multicolumn{8}{|c|}{ Antibiotics } \\
\hline & Ro (\%) & R1 (\%) & R2 (\%) & R3 (\%) & R4 (\%) & MDR (\%) & ESBL producers(\%) & Total (\%) \\
\hline Gram Negative & $1(2.1)$ & $1(2.1)$ & $5(10.6)$ & $20(42.6)$ & $20(42.6)$ & $41(87.2 \%)$ & $12(25.5)$ & $47(100)$ \\
\hline E.coli & $0(0.0)$ & $1(2.8)$ & $2(5.6)$ & $18(50)$ & 15(41.6) & $33(88.9)$ & $10(27.8)$ & $36(100)$ \\
\hline K. pneumonia & $1(16.7)$ & $0(0.0)$ & $1(16.7)$ & $2(33.3)$ & 2(33.3) & $5(83.3)$ & $2(33.3)$ & $6(100)$ \\
\hline Citrobacter spp. & $0(0.0)$ & $0(0.0)$ & $1(50)$ & $0(0.0)$ & $1(50)$ & $1(50)$ & $0(0.0)$ & $2(100)$ \\
\hline P.mirabilis. & $0(0.0)$ & $0(0.0)$ & $1(50)$ & $0(.00)$ & $1(50)$ & $1(50)$ & $0(0.0)$ & $2(100)$ \\
\hline Enterobacter spps. & $0(0.0)$ & $0(.00)$ & $0(.00)$ & $0(0.0)$ & $1(100)$ & $1(100)$ & $0(0.0)$ & $1(100)$ \\
\hline Gram positive & $5(18.5)$ & $4(14.8)$ & $4(18.5)$ & $8(29.6)$ & $6(18.5)$ & $13(48.1 \%)$ & NT & $27(100)$ \\
\hline CoNS & $4(23.5)$ & $2(11.8)$ & $3(17.6)$ & $5(29.5)$ & $3(17.6)$ & $7(41.2)$ & NT & $17(100)$ \\
\hline S. aureus & $1(10)$ & $2(20)$ & $1(10)$ & $3(30)$ & $3(30)$ & $6(60)$ & NT & 10(100) \\
\hline Total & $6(8.1)$ & $5(6.8)$ & $9(12.2)$ & 28(37.8) & $26(35.1)$ & $54(73.0)$ & $12(25.5)$ & $74(100)$ \\
\hline
\end{tabular}

Key;R0- susceptible to allantibiotics, R1- Resistance to one antibiotic, R2-Resistance to antibiotics, R3-Resistance to threeantibiotics, $\geq$ R4-resistance to four and above antibiotics, NT not test, MDR Multidrug resistant: non-susceptible to at least one agent in three antimicrobial categories [65]. Based on this definition, the following antimicrobial categories were considered to determine whether the given isolate is MDR Gram positive isolates and Enterobacteriacecae: aminoglycosides (gentamicin), cephems (ceftiraxone), pencillin (ampcillin), beta lactamase inhibitor combination (amoxicillin/clavulanic acid), fluoroquinolones (ciprofloxacin,norfloxacin), nitrofuran (nitrofurantoin), cotrimoxazole, tetracycline and phenicols (chloramphenicol). Of these, nalidixic acid and macrolides (erythromycin) was used only for enterobacteriacecae and Gram positive isolates 
Table 6 Risk factors associated with UTI among Mekelle University students with symptomatic UTI, northern Ethiopia, FebruarySeptember 2017

\begin{tabular}{|c|c|c|c|c|c|c|c|c|}
\hline \multirow[t]{2}{*}{ Variable } & & \multirow[t]{2}{*}{ Total } & \multicolumn{2}{|c|}{ Significant Bacteriuria } & \multirow[t]{2}{*}{ COR (95\% Cl) } & \multirow{2}{*}{$\begin{array}{l}p- \\
\text { value }\end{array}$} & \multirow[t]{2}{*}{ AOR $(95 \% \mathrm{Cl})$} & \multirow{2}{*}{$\begin{array}{l}p- \\
\text { value }\end{array}$} \\
\hline & & & Yes (\%) & No (\%) & & & & \\
\hline \multicolumn{9}{|l|}{ Sex } \\
\hline Male & & 97 & $8(8.2)$ & 89(91.8) & 1 & & & \\
\hline Female & & 244 & $64(26.2)$ & 180(73.8) & $3.96(2.45-14.02)$ & 0.001 & $7.42(1.25-43.96)$ & $0.027^{*}$ \\
\hline \multicolumn{9}{|l|}{ Age (in years) } \\
\hline $16-20$ & & 29 & $5(17.2)$ & $24(82.8)$ & 1 & & & \\
\hline $21-25$ & & 217 & $46(21.2)$ & $171(78.8)$ & $1.29(0.242-3.26)$ & 0.752 & NA & \\
\hline $26-30$ & & 90 & $21(23.3)$ & $69(76.7)$ & $1.46(0.41-6.24)$ & 0.505 & NA & \\
\hline $31-35$ & & 5 & $0(0.0)$ & $5(100.0)$ & NA & & & \\
\hline \multicolumn{9}{|l|}{ Current symptoms } \\
\hline \multirow[t]{2}{*}{ Dysuria } & No & 91 & 9 & 82 & 1 & & & \\
\hline & Yes & 250 & 63 & 187 & $3.06(1.263-5.632)$ & 0.010 & $3.38(1.001-11.44$ & 0.052 \\
\hline \multirow[t]{2}{*}{ Frequency } & No & 96 & 13 & 83 & 1 & & & \\
\hline & Yes & 245 & 59 & 186 & $2.02(1.004-3.593)$ & 0.048 & $0.73(0.279-1.93)$ & 0.534 \\
\hline \multirow[t]{2}{*}{ Urgency } & No & 110 & 14 & 103 & 1 & & & \\
\hline & Yes & 231 & 58 & 173 & $2.46(1.567-5.719)$ & 0.001 & $1.605(.637-4.046)$ & 0.316 \\
\hline \multirow[t]{2}{*}{ Hematuria } & No & 290 & 51 & 239 & 1 & & & \\
\hline & Yes & 51 & 21 & 30 & $3.28(1.370-6.34)$ & 0.006 & $0.812(0.26-2.58)$ & 0.725 \\
\hline \multirow[t]{2}{*}{ Abdominal pain } & No & 80 & 13 & 67 & 1 & & & \\
\hline & Yes & 261 & 59 & 202 & $1.50(.813-3.040)$ & 0.179 & NA & \\
\hline \multirow[t]{2}{*}{ Fever } & No & 147 & 30 & 117 & 1 & & & \\
\hline & Yes & 194 & 42 & 152 & $1.07(.633-1.795)$ & 0.811 & NA & \\
\hline \multirow[t]{2}{*}{ Flank pain } & No & 248 & 39 & 209 & 1 & & & \\
\hline & Yes & 93 & 33 & 60 & $2.95(2.12-10.955)$ & 0.001 & $3.776(1.552-9.18)$ & $0.003^{*}$ \\
\hline \multirow[t]{2}{*}{ Urinary Incontinence } & No & 215 & 29 & 186 & 1 & & & \\
\hline & Yes & 126 & 43 & 83 & $3.32(3.007-9.116)$ & 0.001 & $2.07(0.855-4.99)$ & 0.107 \\
\hline
\end{tabular}

as an antimicrobial agent; and having warm and moist urethra which could be supportive for the optimal growth of bacteria compared to males [43]. Also besides, other behavioral factors such as the mechanical introduction of pathogens into the bladder and trauma effect during sexual intercourse could also be a reason for this high prevalence of UTI among female individuals [44].

As studies have been documented in the general populations the etiologic agents of UTI mostly belong to Gram-negative bacteria [15, 21]. Likewise,63.5\% isolates of the present study were Gram-negative bacteria. Of all, E. coli was the most frequent bacterial isolate with a $48.6 \%$ isolation rate. This isolation rate of E. coli was similar to earlier findings reported in other parts of Ethiopia (47.5\%) [45] and (44.62\%) [37]; and Sudan (47.3\%) [46]. The possible explanation for this high isolation rate of $E$. coli in the present finding could be due to the contamination of the urinary tract from the rectal area and it could also be due to $E$. coli has various enhanced virulence factors specific for colonization and invasion of the urinary epithelium [35]. The second most common isolate was CoNS(23.0\%). This was in line with findings reported from the general population in Ethiopia (22.5\%) [46] and (22\%) [47]. This could be as CoNS are a normal flora of the urogenital area at puberty, which may invade the urinary tract during sexual activity especiallyinfemales [1]. Isolation rate of S.aureus (13.5\%) and K.pneumoniae (.1\%) in our study was comparable to previous reports in Nigeria (13.3\%) and (6.4\%)respectively [37]. Similar to previously conducted studies in Ethiopia [47], (2.8\%) of mixed bacterial pathogens were isolated in the present study.

The present study showed participants with a past history of UTI had significantly higher prevalence UTI compared to those with no previous history UTI $(P=$ $0.005)$. This was similar to findings reported in Ethiopia $[29,47]$ and another place [11]. The possible explanation 
Table 7 Association of Other Enabling Factors with UTI among Mekelle University Students with Symptomatic UTI, Northern Ethiopia, February-September 2017

\begin{tabular}{|c|c|c|c|c|c|c|c|}
\hline \multirow[t]{2}{*}{ Variable } & \multirow[t]{2}{*}{ Total } & \multicolumn{2}{|c|}{$\underline{\text { Significant Bacteriuria }}$} & \multirow[t]{2}{*}{ COR $(95 \%, \mathrm{Cl})$} & \multirow{2}{*}{$\begin{array}{l}p- \\
\text { value }\end{array}$} & \multirow[t]{2}{*}{ AOR $(95 \%, C l)$} & \multirow{2}{*}{$\begin{array}{l}p \text { - } \\
\text { value }\end{array}$} \\
\hline & & Yes & No & & & & \\
\hline \multicolumn{8}{|l|}{ History of UTI } \\
\hline No & 299 & 46 & 253 & 1 & & & \\
\hline Yes & 42 & 26 & 16 & $8.93(5.27-28.14)$ & 0.001 & $5.75(1.70-19.4)$ & $0.005^{*}$ \\
\hline \multicolumn{8}{|l|}{ History of DM } \\
\hline No & 316 & 66 & 250 & 1 & & & \\
\hline Yes & 15 & 6 & 9 & $2.52(.130-12.411)$ & 0.836 & NA & \\
\hline \multicolumn{8}{|l|}{ Using contraceptive } \\
\hline No & 313 & 60 & 253 & 1 & & & \\
\hline Yes & 28 & 12 & 16 & $3.16(2.30-8.427)$ & 0.001 & $1.14(0.412-3.17)$ & 0.798 \\
\hline \multicolumn{8}{|l|}{ History of Medication } \\
\hline No & 297 & 57 & 240 & 1 & & & \\
\hline Yes & 44 & 15 & 29 & $2.17(1.53-14.46)$ & 0.001 & $1.98(0.422-9.27)$ & 0.386 \\
\hline \multicolumn{8}{|l|}{ History of Catheter } \\
\hline No & 330 & 66 & 264 & 1 & & & \\
\hline Yes & 11 & 6 & 5 & $4.8(1.68-22.387)$ & 0.006 & $18.2(4.45-74.77)$ & $0.001^{*}$ \\
\hline \multicolumn{8}{|l|}{ Male Circumcision } \\
\hline No & 19 & 3 & 16 & $2.73(2.120-14.063)$ & 0.001 & $3.89(0.66-71.56)$ & 0.106 \\
\hline Yes & 78 & 5 & 73 & 1 & & & \\
\hline \multicolumn{8}{|l|}{ Female Sexual Activity } \\
\hline Never had Sex & 177 & 43 & 134 & 1 & & & \\
\hline Had sex $<3$ per week & 61 & 16 & 45 & $1.1(1.004-3.593)$ & 0.048 & $1.605(0.637-4.05)$ & 0.316 \\
\hline Had sex $\geq 3$ per week & 11 & 5 & 6 & $2.59(1.26-6.12)$ & 0.015 & $2.16(1.149-3.69)$ & $0.012^{*}$ \\
\hline
\end{tabular}

Note: *Statistically significant at $P<0.05 . \mathrm{DM}$, diabetes mellitus; AOR adjusted odds ratio, COR crude odds ratio, 1 referent group, $\mathrm{Cl}$ confidence interval, $N / A$ not applicable

for this association could be due to the existence of resistant strains from the earlier uropathogens.

In line with previously documented results $[1,3,11]$ our study revealed, female participants had seven folded increased risk of acquiring UTI. This might be due to females have short, wider and direct urethra, lack of prostatic fluid which acts as antimicrobial; and having warm and moist urethra which could be supportive for the optimal growth of bacteria compared to males [37]. The history of catheterization was also found significantly associated with the presence of UTI in this study $(p<$ 0.001). This was similar to a study done in Ethiopia [43]. This could be due to contamination while catheter insertion, frequent and long-term catheterization which supports adherence of pathogens to the urinary tract. Sexual activity was also the other risk factor that was found to be statistically associated with UTI. Females who had recent sexual intercourse of three or more per week were two times more likely to have UTI than females who had less than three intercourses per week. This was in line with the result of the previous study in Ethiopia
[29]. The possible explanation for this association could be due to the frequent use of contraceptives in addition to having frequent intercourse may push the bacteria into the bladder as explained above [29].

In line with earlier documented findings [2, 39, 48]; age and history of antibiotics had no association with UTI in the present study. Moreover, contrary to the previous report [46] the present study revealed, using contraceptives, circumcision and having diabetics' Mellitus had no significant association with the presence of UTI.

Our study revealed Gram-negative isolates were $100 \%$ resistant to ampicillin. This rate of resistance was similar to the previous study done in Ethiopia [45] and Nigeria [39] who reported (100\%).In contrast to the previous documented resistant rate of Gram-negative bacteria to amoxicillin/clavulanic acid in Ethiopia (30\%) [45], and (40.7\%) [35], a higher rate of resistance was observed in our study (93.6\%). This resistance rate was similar to a report from Nigeria (96.5\%) [29]. This high resistance rate of Gram-negative isolates against amoxicillin/clavulanic acid could be due to the production of 
inhibitors resistant $\beta$-lactamase. The resistance rate of Gram-negative isolates to co-trimoxazole and nalidixic acid was $(72.3 \%)$ and $(57.4 \%)$ respectively. These rates of resistance were comparable to previous reports from Uganda co-trimoxazol (80\%) [49]; India, nalidixic acid (51\%) [50]. The factors contributing to those resistance rates might be due to the irrational use /self-medication of antibiotics in the study area that is common [8]. However, the resistance rate of Gram-negative isolates to tetracycline $(46.8 \%)$ in the present study was lower compared to the previous report in Ethiopia (76.9\%) [37]. generally, most Gram-negative isolates of the present study were sensitive to ciprofloxacin (85.1\%), ceftriaxone (83.0\%), norfloxacin $(80.8 \%)$, nitrofurantoin $(78.7 \%)$ and chloramphenicol (74.5\%). This finding was in line with previous findings from Bangladesh [34] and Nigeria [39] where ciprofloxacin, ceftriaxone, norfloxacin, nitrofurantoin, and chloramphenicol were effective to Gram-negative isolates.

Among Gram-positive isolates $S$. aureus showed a high resistance rate to ampicillin and amoxicillin/clavulanic acid ( $90 \%$ each), co-trimoxizole $(80 \%)$ followed by tetracycline (60\%) and erythromycin (50\%). This high trend of resistance was comparable with earlier documented results in Ethiopia, ampicillin (87.5-100\%) [48] and tetracycline (57.1\%) [2]. This higher resistance rate of $S$. aureus could be due to the production of penicillinase enzymes and other alternative penicillin-binding proteins which helps the organism to become resistant to $\beta$ lactam antibiotics in addition to the other resistance mechanisms and irrational use of these antibiotics. Generally, gram-positive isolates of the present study were highly resistant to ampicillin(81.5\%), amoxicillin/clavulanic acid (77.8\%), co-trimexazole(55.6\%), and erythromycin(48.2\%). This resistance rate was a bit lower compared to finding reported in Nigeria, ampicillin $(88.9 \%)$ and tetracycline (66.7\%) [39]. It was, however, comparable with the previously documented results in Ethiopia which resistance rate to tetracycline and co-trimexazole was around (50\%) [21]. On the contrary, the resistance rate of Gram-positive isolates to erythromycin and amoxicillin/clavulanic acid of this study was higher than an earlier study conducted in Ethiopia which showed resistance rate to erythromycin $(25 \%)$ and amoxicillin/clavulanic acid (0\%) [21]. This might be due to inappropriate use and incorrect administration of these antibiotics in addition to other factors like strain and geographic variation.

The overall prevalence of MDR in this study (73\%) was comparable with the previous finding in Nigeria (81.4\%) [28]. However, our result was lower than earlier reported prevalence of MDR from Ethiopia (95-100\%) $[2,45]$. In contrast, the result of this study was higher than other documented results in Ethiopia (59.8\%) [47].
The high prevalence of MDR in the present study could also be due to multiple resistant genes that can develop on the mobile genetic elements [51] and plasmids bearing genes-encoding ESBLs, frequently also carry genes encoding resistance to other antimicrobial agents [52]. Self-medication which is a common practice in the study area [8] also might have a great role in the development of such a higher prevalence of MDR [28].

The treatment choice of ESBL-producing organisms is very restricted [52]. Similar to a previously reported article in western India (21.3\%) [50], the overall ESBL production of Gram-negative isolates of the present study was $25.5 \%$. ESBL production of Klebsiella isolates (33.3\%) in the present study was similar to previous findings in Ethiopia (33.3\%) [53]. However, the overall ESBL production of this study was lower compared to finding reported in Ethiopia (78.57\%) [54] and Nigeria, 34.9\% [29]. This high ESBL production of isolates might be due to uncontrolled antibiotic usage, inappropriate dosing regimens and substandard antibiotics which are a risk factor for the acquisition of an ESBL-producing organism [52].

\section{Conclusion}

In the present study, the overall prevalence of UTI was $21.1 \%$. Being female, the previous history of catheterization, prior history of UTI and frequent sexual activity had a statistically significant association with the occurrence of UTI.E. coli was the most dominant isolate followed by CoNS and most of the isolates were highly resistant to ampicillin, amoxicillin/clavulanic acid and co-trimoxazole followed by nalidixic acid and tetracycline. MDR was seen in $73 \%$ of the isolates and $25.5 \%$ of the Gram-negative bacteria were ESBL producers. Safe sexual intercourse, safe catheterization should be applied to lessen the magnitude UTI. Therefore, from this study, there is a significant increase in UTI and antibiotic resistance in university students. Our study suggests early diagnosis and initiation antibiotic for UTI and antimicrobial susceptibility tests should be recommended to prevent serious complications.

\footnotetext{
Abbreviations

ATCC: American Type Culture Collection; CFU: Colony Forming Unit; CLSI: Clinical and Laboratory Standards Institute; CoNS: Coagulase-negative staphylococci; DM: Diabetes Mellitus; ESBL: Extended-Spectrum BetaLactamase; MSU: Midstream Urine; MU: Mekelle University; SB: Significant Bacteriuria; SD: Standard Deviation; SPSS: Statistical Package for Social Science; TSI: Triple Sugar Iron Agar; US: United States; UTI: Urinary Tract Infection; WHO: World Health Organization
}

Acknowledgments

We are grateful to Mekelle University College of health science laboratory personnel, Mekelle University student clinic health professionals and study participants for their contribution to this research work. 


\section{Authors' contributions}

GG designed the study, collected, entered, did lab work, analyzed, interpreted the data, and prepared the draft manuscript. AGW, YW, HL, TA, and $\mathrm{KH}$ contributed to data analysis, interpretation and prepared the manuscript for publication. All authors read and approved the final manuscript.

\section{Funding}

Not applicable.

\section{Availability of data and materials}

The datasets used and analyzed during the current study are available from the corresponding author on reasonable request.

\section{Ethics approval and consent to participate}

Ethical approval was sought from Mekelle University, College of Health Science, and Health Research Ethics Review Committee (HRERC) and was granted accordingly with the reference number (ERC0949/2017). Official support letters were submitted to the study clinics. Informed written consent was obtained from each study participant. Participants were also informed that they are free to withdraw from the study at any time and their medical records were kept strictly confidential. Culture and sensitivity results were communicated to the patient's respective clinician for beneficiary measures,

\section{Consent for publication}

Individual data such as images and videos did not accompany this particular manuscript and hence consent for publication is not applicable.

\section{Competing interests}

The authors declare that they have no competing interests.

\section{Received: 18 December 2018 Accepted: 31 October 2019} Published online: 08 November 2019

\section{References}

1. Michael OO, Adenike AV. Asymptomatic bacteriuria: occurrence and antibiotic susceptibility profiles among students of a tertiary institution in lle-lfe, Nigeria. Afr J Microbiol Res. 2016;10(15):505-10.

2. Derese B, Kedir H, Teklemariam Z, Weldegebreal F, Balakrishnan S. Bacterial profile of urinarytract infection and antimicrobial susceptibility pattern among pregnant women attendingat antenatal Clinic in Dil Chora Referral Hospital, Dire Dawa, eastern Ethiopia. Ther Clin Risk Manag. 2016;12:251-60.

3. Khoshbakht R, Salimi A, Shirzad HA, Keshavarzi H. Antibiotic susceptibility of bacterial strains isolated from urinary tract infections in Karaj, Iran. Jundishapur J Microbiol. 2013;6(1):86-90.

4. Gabriel HB, Shehu F. Prevalence and antibiotic susceptibility patterns of bacterial etiologies of urinary tract infections among students attending Sick-Bay of Ahmadu Bello University, Nigeria. Edorium J Microbiol. 2016; 2:7-12.

5. Vyas S, Varshney D, Sharma P, Juyal R, Nautiyal V, Shrotriya VP. An overview of the predictors of symptomatic urinary tract infection among nursing students. Anal Med Health Sci Res. 2015;5(1):54-8.

6. Akinjogunla OJ, Divine-Anthony O. Asymptomatic bacteriuria among apparently healthy undergraduate students in uyo, South-South, Nigeria. ARRB. 2013:3(3):213-25

7. Agersew A, Chandrasekhar U. Prevalence and antimicrobial susceptibility pattern of urinary tract infection causing human pathogenic bacteria among symptomatic outpatients, visiting Gondar University hospital Gondar, Northwest Ethiopia. Novus Int J Med Sci. 2013;2(2):1-14.

8. Eticha T. Prevalence and predictors of self-medication with antibiotics among Adi-haqi Campus students of Mekelle University, Ethiopia. IJPSR. 2014;5:678-84.

9. Omoregie R, Erebor JO, Ahonkhai I, Isibo JO, Ogefere HO. Observed changes in the prevalence of uropathogens in Benin City, Nigeria. N Z J Med Lab Sci. 2008:62:29-31.

10. Foxman B, Zhang L, Tallman P, Bonnie CA, Ann MG, James SK, et al. Transmission of Uropathogens between sex partners. J Infect Dis. 1997; 175:989-92

11. Wei CT, Piotr MC. Urinary tract infections in adults. Singap Med J. 2016;57(9): 485-90.

12. Griebling TL. Urinary tract infection in men. NIH. 2007;7:621-45.
13. Olson PD, Hruska KA, Hunstad DA. Androgens enhance male urinary tract infection severity in a new model. J Am Soc Nephrol. 2015;27:1-10.

14. Nienhouse V, Gao X, Dong Q, Nelson DE, Toh E, McKinley K, et al. Interplay between bladder microbiota and urinary antimicrobial peptides: mechanisms for human urinary tract infection risk and symptom severity. PLOS One. 2014;9(12):114-85.

15. CLSI: Performance standards for antimicrobial susceptibility testing; $15^{\text {th }}$ International supplement. CLSI document M100 S15, Wayne: Clinical and Laboratory Standards Institute.2005;25(6):1-215.

16. Daoud Z, Afif C. Escherichia coli isolated from urinary tract infections of Lebanese patients between 2000 and 2009: epidemiology and profiles of resistance. Chemother Res Pract. 2011;6:1-6.

17. Flores-Mireles AL, Walker JN, Caparon M, Hultgren SJ. Urinary tract infections: epidemiology, mechanisms of infection and treatment options. Nat Rev Microbiol. 2015;13:271-84.

18. Mpotane T, Ntswabule V, Mcpherson C, Botes E. The role of toilet hygiene in transmission of vaginal and urinary tract infections in Huis Welgemoed, Cut campu. AJMR. 2012;14:26-31.

19. Fouad M, Boraie M. Prevalence of asymptomatic urinary abnormalities among adolescents. Saudi J Kidney Dis Transpl. 2016;27(3):500-6.

20. Nwosu DC, Amajioyi O, Ibebuike JE, Ozims SJ. Prevalence of bacterial and parasitic urinary tract infections in female students of Imo state University. WJPPS. 2015:4(5):152-67.

21. Demilie T, Beyene G, Melaku S, Tsegaye W. Urinary bacterial profile and antibiotic susceptibility pattern among pregnant women in north West Ethiopia. Ethiop J Health Sci. 2012;22(2):121-8.

22. Deepthy BJ, Suresh G, Saleel M. Study of the spectrum and antibiotic resistance of uropathogens isolated from hospital and community patients. Int J Recent Sci Res. 2015;6(4):3265-6.

23. Olayemi OJ, Olayinka BO, Musa Al. Evaluation of antibiotic self-medication pattern amongst undergraduate students of Ahmadu Bello University (Main campus), Zaria. Res J Appl Sci Eng Technol. 2010;2(1):35-8.

24. Afolabi MO, Macarthy L, Osemene KP. Use of antimicrobial medicines among UniversityStudents in Sierra Leone. BJPR. 2014:4(1):101-12.

25. Donkor ES, Tetteh-Quarcoo PB, Nartey P, Agyeman IO. Self-medication with antibiotics among tertiary level students in Accra, Ghana: a cross-sectional study. Int J Environ Res Public Health. 2012;9:3519-29.

26. Stefaniu E, Suchocka U, Bosacka K, Hryniewicz W. Etiology and antibiotic susceptibility of bacterial pathogens responsible for community-acquired urinary tract infections in Poland. Eur J Clin Microbiol Infect Dis. 2016;35:1363-9.

27. Behailu D, Haji KZ, Fitsum W, Senthilkumar B. Bacterial profile of urinarytract infection and antimicrobial susceptibility pattern among pregnant women attendingat antenatal Clinic in Dil Chora Referral Hospital, Dire Dawa, eastern Ethiopia. Ther Clin Risk Manag. 2016;12:251-60.

28. Alabi OS, Onyenwe NE, Satoye KA, Adeleke OE. Prevalence of extendedspectrum $\beta$-lactamase producing isolates from asymptomatic bacteriuria among students in a tertiary institution in Ibadan, Nigeria. J Nat Sci. 2014:12(4):111-4.

29. Emiru T, Beyene G, Tsegaye W, Melaku S. Associated risk factors ofurinary tract infection among pregnant women at Felege Hiwot referral hospital, BahirDar, North West Ethiopia. BMC Res Notes. 2013;6:292.

30. Cheesbrough M. Biochemical tests to identify bacteria. In District Laboratory Practice in Tropical Countries, Part 2. Cambridge: Cambridge University Press; 2000. p. 63-70.

31. Magiorakos AP, Srinivasan A, Carey RB, Carmeli Y, Falagas ME, Giske CG, et al. Multidrug-resistant, extensively drug-resistant and pan drugresistantbacteria:an international expert proposal for interim standard definitions for acquired resistance. Clin Microbiol Infect. 2012;18:268-81.

32. Clinical and Laboratory standards Institute: Performance standards for antimicrobial susceptibility testing. Twenty-Six Informational Supplement. Wayne, 2016; 36(1).

33. Bishop HG, Shehu F. Prevalence and antibiotic susceptibility patterns of bacterial etiologies of urinary tract infections among students attending Sick-Bay of Ahmadu Bello University, Nigeria. Edorium J Microbiol. 2016; 2:7-12.

34. Yusuf A, Begum A, Ahsan CR. Antibiotic sensitivity pattern of gram negative uropathogenicbacilli at a private hospital in Dhaka city. Al Ameen J Med Sci. 2015;8(3):189-94.

35. Kabew G, Abebe $T$, Miheret A. A retrospective study on prevalence and antimicrobial susceptibility patterns of bacterial isolates from urinary tract 
infections in Tikur Anbessa specialized teaching hospital Addis Ababa, Ethiopia. Ethiop J Health Dev. 2013;27(2):112-7.

36. Ngwa YB, lliyasu H, Young E, Owuna G. Bacteriuria and antimicrobial susceptibility of escherichia coli isolated from urine of asymptomatic university students in kef, Nigeria. Jundishapur J Microbiol. 2012;5(1):323-7.

37. Ayoade F, Moro DD, Ebene OL. Prevalence and antimicrobial susceptibility pattern of asymptomatic urinary tract infections of bacterial and parasitic origins among university students in redemption camp, Ogun State, Nigeria. OJMM. 2013;3:219-26.

38. Sharma E, Thakuriya R, Kumar HG. Study of predictors of urinary tract infections in nursing. IJRTSAT. 2015;15(3):442-3.

39. Nsofor CA, Obijuru CE, Ozokwor CL. Asymptomatic bacteriuria among female students of a tertiary institution in southeast Nigeria. AJRPSB. 2016; 4(2):38-44.

40. Wogu MD, Ogbebor NE. Prevalence of asymptomatic bacteriuria in secondary schoolstudents in Benin City. EIJMR. 2011;5(4):145-51.

41. Helen OO, Ossai OS. Asymptomatic bacteriuria among secondary school students in Benin City, Nigeria. JPHE. 2013;5(2):66-9.

42. Christiana AO, Perpetua ON, Obasi OS. Burden of urinary tract infection among female students: south eastern Nigeria side of the story. IJTDH. 2016; 12(2):1-7.

43. Melaku S, Kibret M, Abera B, Gebre-Sellassie S. Antibiogram of nosocomia urinary tract infections in Felege Hiwot referral hospital from Ethiopia. Afr Health Sci. 2012;12:134-9.

44. Kurt GN. Treatment options for acute uncomplicated cystitis in adults. J Antimicrob Chemother. 2000:46(1):23-7.

45. Alemu A, Moges F, Shiferaw Y, Tafess K, Kassu A, Anagaw B, et al. Bacterial profile and drug susceptibility pattern of urinary tract infection in pregnant women at university of Gondar teaching Hospital, northwest Ethiopia. BMC Res Notes. 2012;5:197.

46. Ahmed OB. Bacterial profile and antimicrobial susceptibility pattern of urinary tract infection in Khartoum, Sudan. Int J Curr Res. 2015;7(11):22344-7.

47. Yismaw G, Asrat D, Woldeamanuel Y, Unakal CG. Urinary tract infection: bacterial etiologies, drug resistance profile and associated risk factors in diabetic patients attending Gondar University hospital, Gondar, Ethiopia. Euro J Exp Bio. 2012;2(4):889-98.

48. Wondimeneh Y, Muluye D, Alemu A, Atinafu A, Yitayew G, Gebrecherkos T, et al. Urinary tract infection among obstetric fistula patients at Gondar University Hospital, Northwest Ethiopia. BMC Women's Health. 2014;14:1-6.

49. Mwaka AD, Mayanja-Kizza H, Kigonya E, Kaddu-Mulindwa D. Bacteriuria among adult non-pregnant women attending Mulago hospital assessment Centre in Uganda. Afr Health Sci. 2011;11(2):182-7.

50. Jadhav S, Hussain A, Devi S, Kumar A, Parveen S, Gandham N, et al. Virulence characteristics and genetic affinities of multiple drug resistant uropathogenic Escherichia coli from a semi urban locality in India. Plos One. 2011;6(3):e18063 doi: 10.1371 /journal .pone .0018063.

51. Gillespie SH, Bamford KB. Resistance to antibacterial agents. InMedical Microbiology and Infection ata Glance. 4th ed. UK: Wiley-Blackwell; 2012. p. 20-2

52. Rawat $D$, Nair $D$. Extended-spectrum $\beta$-lactamases in gram negative bacteria. J Glob Infect Dis. 2010;2(3):263-74.

53. Seid J, Asrat D. Occurrence of extended spectrum beta -lactamase enzymes in clinical isolates of Klebsiella species from Harar region, eastern Ethiopia. Acta Tropica. 2005;95:143-8.

54. Hailu ML, Mulugeta GW, Asrat D. Extended-spectrum beta-lactamase- and carbapenemase-producing Enterobacteriaceae among Ethiopian children. Infect Drug Resi. 2017;10:27-34.

\section{Publisher's Note}

Springer Nature remains neutral with regard to jurisdictional claims in published maps and institutional affiliations.

Ready to submit your research? Choose BMC and benefit from:

- fast, convenient online submission

- thorough peer review by experienced researchers in your field

- rapid publication on acceptance

- support for research data, including large and complex data types

- gold Open Access which fosters wider collaboration and increased citations

- maximum visibility for your research: over $100 \mathrm{M}$ website views per year

At BMC, research is always in progress.

Learn more biomedcentral.com/submissions 